\title{
Feeding ecology of the catfish Ictalurus punctatus (Siluriformes: Ictaluridae) in a reservoir in Northeast Mexico
}

\author{
Cardoza-Martínez, Gabriel F. ${ }^{1}$; Bojórquez-Moreno, Cristo A. ${ }^{1}$; Czaja, Alexander ${ }^{1}$; Becerra-López, Jorge L. ${ }^{1}$; \\ Garza-Martínez, Miguel A. ${ }^{1}$; Estrada-Arellano, Josué R. ${ }^{1}$; Cerano-Paredes, Julián ${ }^{2}$; \\ Estrada-Rodríguez, José L. ${ }^{1}$; Alonzo-Rojo, Fernando ${ }^{1^{*}}$
}

${ }^{1}$ Facultad de Ciencias Biológicas. Universidad Juárez del Estado de Durango. Av. Universidad S/N, Fracc. Filadelfia, Gómez Palacio, Durango, México. C. P. 35010.

2 Instituto Nacional de Investigaciones Forestales, Agrícolas y Pecuarias. Centro Nacional de Investigación Disciplinaria en Relación Agua, Suelo, Planta, Atmósfera. Margen Derecha del Canal Sacramento km 6.5, Gómez Palacio, Durango, México. C. P. 35140.

* Corresponding author: falonzor@gmail.com

\begin{abstract}
Objective: To determine the main food of the catfish according to seasonal variability and the sex of the organism in the Venustiano Carranza Dam, Coahuila, Mexico.

Methodology: In total, 143 catfish stomachs from different seasons were examined. In the analysis of the stomach content, the detected organisms were determined until the taxonomic order rank. The seasonal and sex feeding variability were also analyzed. The Relative Importance Index and the Alimentary Index were applied. Non-parametric tests were carried out to compare stomach content between seasons and sexes.

Results: The total annual trophic spectrum for catfish consisted of 13 items, of which only the order Ephemeroptera was categorized as a frequent food. In the winter season the catfish consumed significantly more food compared to the other seasons, but there was no difference in the amount consumed by females and males ( $p>0.05)$.

Implications: This information is relevant to highlight the importance of the biological integrity of the terrestrial site which surrounds the reservoir as a source of food for the catfish.

Conclusions: Catfish channel in the Venustiano Carranza Dam is a generalist species (13 alimentary items). There was a difference in food consumed during the different seasons of the year. However, there was no difference between the sexes.
\end{abstract}

Keywords: Fishery, food resources, freshwater management.

Citation: Cardoza-Martínez, Gabriel F., Bojórquez-Moreno, Cristo A., Czaja, Alexander, Becerra-López, Jorge L., Garza-Martínez, Miguel A., EstradaArellano, Josué R., Cerano-Paredes, Julián, Estrada-Rodríguez, José L., \& Alonzo-Rojo, Fernando. (2021). Feeding ecology of the catfish Ictalurus punctatus (Siluriformes: Ictaluridae) in a reservoir in Northeast Mexico. (2021). Agro Productividad, 14(\#). https://doi. org/10.32854/agrop.v14i6.1931

Editor in Chief: Dr. Jorge Cadena Iñiguez

Estimated publication date: July 2021

This work is licensed under a Creative Commons Attribution-NonCommercial 4.0 International license

\section{INTRODUCTION}

Diversity and availability of food is a determining factor in fish populations because it affects parameters such as migration, behaviors, and temporal and spatial distribution (Behzadi et al., 2018). The analysis of stomach contents of fish is a common practice to understand trophic relationships and flow of matter and energy in ecosystems. This knowledge contributes to fishery management programs and other inland waters fishing systems (Jacquemin et al., 2014). There is great diversity in the way the different groups of fish feed and this also varies from one species to another. This can vary from a high degree of specialization to species which are generalist (Behzadi et al., 2018; Mar et al., 2014). The genus Ictalurus includes piscivor-omnivorous species, which have feeding preferences in bottoms of water bodies in semi-intensive or extensive systems (Arce-H et al., 2017). Within this genus, one of the species with the greatest economic and nutritional importance worldwide is I. punctatus, whose production increased from $15.909 \mathrm{t}$ in 1965 to $432.931 \mathrm{t}$ in 2016 (FAO, 2021). In the federal state of Coahuila, Mexico, the species I. punctatus is reported as the second freshwater 
species of commercial importance, with a production of $281 \mathrm{t}$ in 2017 (SIAP, 2017). In this context, it has been reported that in those aquatic species of commercial interest it is important to know the dietary diversity to maintain growth in their sizes and the viability of their populations (Hilling et al., 2016). This is a factor of great importance to address the problem of food security in marginalized areas (Fisher et al., 2017). Some studies on the food ecology and variability of the diet of channel catfish in freshwater systems, in the north-central part of the country, show a tendency of the populations of I. punctatus to consume mainly fish (Perciformes and Atheriniformes) (Tyus and Nikirk, 1990). In other regions of North America the contribution of elements from terrestrial ecosystems in the diet of I. punctatus have been reported (Edds et al., 2002). For example, arthropods and seeds are important components for their diet too (Cardoza et al., 2011). Herein we aimed to know if in our study area, I. punctatus shows selectivity in their eating habits from a seasonal and sexual perspective. The results of the present study allow us to increase information regarding the consumption patterns of I. punctatus resources in arid ecosystems, which may contribute to the management and maintenance of the populations of this species, thus promoting its sustainable use.

\section{MATERIALS AND METHODS}

Study area. The Venustiano Carranza Dam is in the northeast of the state of Coahuila, in northern Mexico, between coordinates $27^{\circ} 25^{\prime} 06^{\prime \prime}, 27^{\circ} 32^{\prime} 21^{\prime \prime} \mathrm{N}$ and $100^{\circ} 34^{\prime} 50^{\prime \prime}, 100^{\circ}$ $45^{\prime} 20^{\prime \prime}$ W (Figure 1). The reservoir has as main tributaries the Sabinas and Nadadores rivers and a storage capacity of 1.385 million $\mathrm{m}^{3}$ of water. The average annual rainfall for the area is $375 \mathrm{~mm}$, the months with highest rainfall are September and October, and the average annual temperature is $22{ }^{\circ} \mathrm{C}$ (CONAGUA, 2018). The main types of vegetation and soil cover for the surrounding area of the reservoir are the microphilic desert scrub, rosetophilic scrub, tamaulipan thornscrub, induced pasture, hydrophilic vegetation, secondary vegetation, and temporary agriculture (INEGI, 2017).

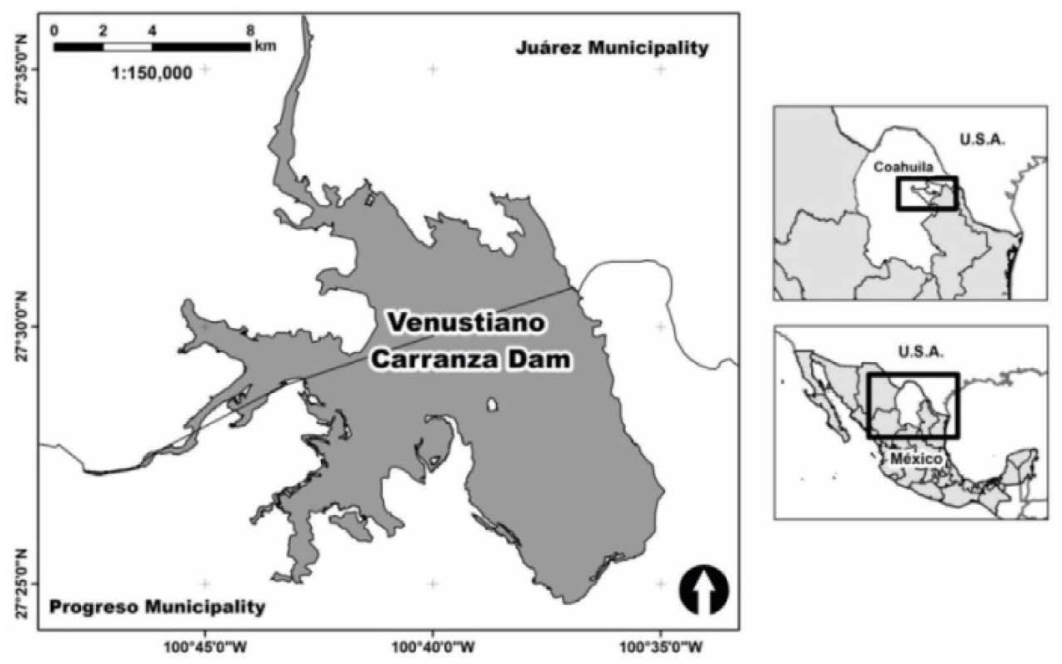

Figure 1. Geographic location of Venustiano Carranza Dam in Coahuila state, Mexico. 
Collection and analysis of samples. Sampling was carried out seasonally in the period from July 2015 to June 2016. In total, 143 catfish individuals were analyzed, which were captured by commercial fishermen of the Venustiano Carranza Dam using gillnets of 2, 3 and 4 inches of mesh opening and $50 \mathrm{~m}$ in length. The seasons were considered as follows: spring (March, April and May), summer (June, July and August), autumn (September, October and November) and winter (December, January and February). Different biometric measurements such as weight, total length (TL), standard length (SL) with the support of a digital field balance (precision of $0.010 \mathrm{~kg}$ ) and an ichthyometer (precision of $1 \mathrm{~cm}$ ) were taken from each specimen (EspinosaPérez, 2014; Valdez-Zenil et al., 2015). To determinate the trophic spectrum of the catfish, an analysis of the stomach contents of the captured organisms was performed. Sex was identified by direct observation of their state of gonadic maturity (Essner et al., 2014). In some organisms the sex could not be determined so they were classified as not determined (Beltrán-Álvarez et al., 2012). Stomachs were transferred to the laboratory for later analysis. The stomach content was analyzed in the laboratory with a stereoscope microscope and was determined to the taxonomic level of order (Cardoza et al., 2011; Mar et al., 2014). Taxonomic determination was based on specialized scientific literature. Undetermined plant or animal matter was considered detritus, with the exception of fish fragments (scales, spines, skin, etc.), which were classified as fish remains (Gerringer et al., 2017). For each food type (item) the abundance (\%N), weight $(\% \mathrm{~W})$, frequency of occurrence $(\% \mathrm{OF})$ and volume $(\% \mathrm{~V})$ were determined (Magnusson et al., 2003; Mar et al., 2014). To estimate the importance of the relation of each food type to total food consumed, the Relative Importance Index (RII) was applied (Pinkas et al., 1970):

$$
\mathrm{RII}=(\% \mathrm{~N}+\% \mathrm{~V}) \times \% \mathrm{FO}
$$

Where $\% \mathrm{~N}$ is the numerical proportional abundance of a food type, $\% \mathrm{~V}$ the volume and $\% \mathrm{FO}$ the frequency of occurrence. To categorize the food items, the Alimentary Index (AI) was applied, which groups the food types based on its relative importance (Lauzanne, 1975):

$$
\mathrm{AI}=\% \mathrm{OF} \times \% \mathrm{~V} / 100
$$

The classification used allows a differentiation between the most used (preferred) food resources, from those that are possibly a product of isolated or accidental eventuality. The result of AI for each item varies from 0 to 100\% and is categorized as follows: a) preferential food (AI>50), b) secondary $(25<\mathrm{AI}<50)$, c) frequent $(10<\mathrm{AI}<25)$ and $\mathrm{d})$ accidental (AI<10) (Lauzanne, 1975; Raymundo-Huizar and Saucedo, 2008). RII and AI were obtained for the total annual food spectrum, by seasons of the year and by sex of the organisms. Finally, because the assumptions of normality and homogeneity of variance for the analyzed data were not met, the non-parametric Kruskal-Wallis test 
was used to determine possible differences in food consumption (weight) between seasons. Similarly, the non-parametric Mann-Whitney test to determine differences in the food consumed (weight) between males and females was applied (Zar, 1999). Statistical analysis was performed with the Past ver. 3.25 software (Hammer et al., 2001).

\section{Results and Discussion}

In total, 143 individuals of channel catfish were analyzed; of which 41 correspond to males, 64 to females and 38 of undetermined sex. The Total Length (TL) of the catfish analyzed varied from 23 to $48 \mathrm{~cm}$. The total annual trophic spectrum for the catfish consist of 13 trophic items or categories, of which 11 correspond to the following orders, based on the Relative Importance Index: Ephemeroptera (mayflies nymphs), Charales (algae), Odonata (dragonfly larvae), Decapoda (crayfish), Cypriniformes (carp eggs), Perciformes and Characiformes (fish), Orthoptera (grasshoppers), Fabales (huizache seeds), Spirobolida (millipedes) and Hemiptera (bugs), as well as the categories of Fish Remains and Detritus (Table 1). According to the Alimentary Index, all food items for annual trophic spectrum were categorized as accidental foods $(\mathrm{AI}<10)$, with the exception of the order Ephemeroptera ( $\mathrm{AI}=11.09)$, which was categorized as a frequent food.

Table 1. Annual trophic spectrum of the catfish in Venustiano Carranza Dam. Numerical Abundance (\%N), Frequency of Occurrence (\%FO), Volume (\%V), Relative Importance Index (RII) and Alimentary Index (AI).

\begin{tabular}{|c|c|c|c|c|c|c|c|}
\hline \multicolumn{2}{|c|}{ Alimentary item } & $\% \mathbf{N}$ & $\% O F$ & $\% \mathrm{~V}$ & RII & $\%$ RII & AI \\
\hline \multirow{6}{*}{ Invertebrates } & Ephemeroptera & 85.920 & 19.608 & 56.572 & 2793.960 & 78.118 & 11.093 \\
\hline & Odonata & 2.299 & 9.804 & 3.267 & 54.569 & 1.526 & 0.320 \\
\hline & Decapoda & 1.437 & 9.804 & 0.879 & 22.702 & 0.635 & 0.086 \\
\hline & Orthoptera & 0.287 & 1.961 & 0.395 & 1.337 & 0.037 & 0.008 \\
\hline & Spirobolida & 0.287 & 1.961 & 0.263 & 1.078 & 0.030 & 0.005 \\
\hline & Hemiptera & 0.287 & 1.961 & 0.128 & 0.814 & 0.023 & 0.003 \\
\hline \multirow{4}{*}{ Fishes } & Cypriniformes & 0.287 & 1.961 & 6.653 & 13.608 & 0.380 & 0.130 \\
\hline & Perciformes & 0.287 & 1.961 & 1.417 & 3.341 & 0.093 & 0.028 \\
\hline & Characiformes & 0.287 & 1.961 & 0.599 & 1.737 & 0.049 & 0.012 \\
\hline & Fish remains & 2.586 & 15.686 & 20.489 & 361.964 & 10.120 & 3.214 \\
\hline Detritus & Detritus & 3.736 & 25.490 & 6.227 & 253.956 & 7.101 & 1.587 \\
\hline \multirow{3}{*}{ Plants } & Charales & 2.011 & 13.725 & 2.825 & 66.389 & 1.856 & 0.388 \\
\hline & Fabales & 0.287 & 1.961 & 0.287 & 1.125 & 0.031 & 0.006 \\
\hline & Total & 100 & & 100 & & 100 & \\
\hline
\end{tabular}

Seasonal feeding analysis. In relation to the seasonal analysis, spring was the period in which the catfish's food spectrum showed the greatest diversity in the use of resources (10 food items). The Detritus and the Fish Remains were the most important resources for this season (63.66\% of the RII). Summer showed the lowest diversity of resources (4 food items). Detritus and the order Charales (algae) were the most important resources in this season (79.56\% of the RII). Decapoda (crayfish) and Charales orders represented $61.76 \%$ of the RII for the autumn season. For the winter 
season, the order Ephemeroptera (ephemeral) individually constitute 95.97\% of the RII. For the spring and autumn seasons all food items were classified as accidental foods $(\mathrm{AI}<10)$, however, in the summer season the Detritus was classified as a frequent food ( $A I=12.90)$. Similarly, the order Ephemeroptera reached the category of secondary food ( $A I=37.50)$ for the winter season. For the last two seasons mentioned, all other food types were classified as accidental (Table 2). The food consumed by the channel catfish represented by weight in the winter season was significantly higher than in the rest of the seasons (Kruskal-Wallis; $\mathrm{H}=12.16$, $\mathrm{p}<0.05$ ). Average food consumed in this season was of $3.44 \pm 1.47 \mathrm{~g}$.

Table 2. Seasonal trophic spectrum to the catfish in Venustiano Carranza Dam. Relative Importance Index (\%RII) and Alimentary Index (AI).

\begin{tabular}{|c|c|c|c|c|c|c|c|c|c|}
\hline \multirow{2}{*}{\multicolumn{2}{|c|}{ Alimentary item }} & \multicolumn{2}{|c|}{ Spring } & \multicolumn{2}{|c|}{ Summer } & \multicolumn{2}{|c|}{ Autumn } & \multicolumn{2}{|c|}{ Winter } \\
\hline & & \multirow{2}{*}{$\begin{array}{c}\text { \%RII } \\
15.845 \\
\end{array}$} & \multirow{2}{*}{$\begin{array}{c}\text { AI } \\
0.537\end{array}$} & \multirow{2}{*}{$\begin{array}{c}\text { \%RII } \\
3.596 \\
\end{array}$} & \multirow{2}{*}{$\begin{array}{c}\mathbf{A I} \\
1.521 \\
\end{array}$} & \multirow{2}{*}{$\begin{array}{l}\text { \%RII } \\
0 \\
\end{array}$} & \multirow{2}{*}{$\begin{array}{c}\text { AI } \\
0\end{array}$} & \multirow{2}{*}{$\begin{array}{c}\text { \%RII } \\
95.976 \\
\end{array}$} & \multirow{2}{*}{$\begin{array}{c}\mathbf{A I} \\
37.50\end{array}$} \\
\hline \multirow{6}{*}{ Invertebrates } & Ephemeroptera & & & & & & & & \\
\hline & Odonata & 4.018 & 0.379 & 0 & 0 & 12.034 & 2.790 & 0.553 & 0.126 \\
\hline & Decapoda & 7.846 & 0.522 & 0 & 0 & 36.123 & 6.816 & 0 & 0 \\
\hline & Orthoptera & 1.425 & 0.211 & 0 & 0 & 0 & 0 & 0 & 0 \\
\hline & Spirobolida & 1.170 & 0.141 & 0 & 0 & 0 & 0 & 0 & 0 \\
\hline & Hemiptera & 0 & 0 & 0 & 0 & 6.497 & 0.788 & 0 & 0 \\
\hline \multirow{4}{*}{ Fishes } & Cypriniformes & 0 & 0 & 0 & 0 & 0 & 0 & 0.851 & 0.754 \\
\hline & Perciformes & 0 & 0 & 0 & 0 & 0 & 0 & 0.214 & 0.161 \\
\hline & Characiformes & 1.820 & 0.320 & 0 & 0 & 0 & 0 & 0 & 0 \\
\hline & Fish remains & 23.694 & 4.357 & 16.840 & 6.202 & 11.155 & 2.472 & 1.922 & 1.714 \\
\hline Detritus & Detritus & 39.969 & 6.479 & 49.212 & 12.904 & 8.546 & 1.529 & 0.484 & 0.295 \\
\hline \multirow{3}{*}{ Plants } & Charales & 2.996 & 0.646 & 30.352 & 7.552 & 25.644 & 3.026 & 0 & 0 \\
\hline & Fabales & 1.216 & 0.153 & 0 & 0 & 0 & 0 & 0 & 0 \\
\hline & Total & 100 & & 100 & & 100 & & 100 & \\
\hline
\end{tabular}

Feeding Analysis by sex of organisms. The food spectrum of the catfish was more diverse for females than for males (11 and 8 items, respectively). The order Ephemeroptera was the most important for both sexes. This order represented $93.74 \%$ and $91.79 \%$ of the RII for both females and males, respectively. The same order was the only one that reached the category of frequent food for both sexes (23.95 and 11.00 AI, for both females and males), the rest of the food was classified as accidental (Table 3). The food consumed by the catfish was $0.86 \pm 0.38 \mathrm{~g}$ for females, while for males it was $0.80 \pm 0.27 \mathrm{~g}$, respectively. There is no significant difference in the food consumed between females and males (Mann-Whitney $U=1196, p>0.05$ for weight). 
Table 3. Trophic spectrum for sex for the catfish in Venustiano Carranza Dam. Relative Importance Index (\%RII) and Alimentary Index (AI).

\begin{tabular}{|c|c|c|c|c|c|}
\hline \multirow{2}{*}{\multicolumn{2}{|c|}{ Alimentary item }} & \multicolumn{2}{|c|}{ Female } & \multicolumn{2}{|c|}{ Male } \\
\hline & & \multirow{2}{*}{$\begin{array}{l}\text { \%RII } \\
93.745 \\
\end{array}$} & \multirow{2}{*}{$\begin{array}{c}\text { AI } \\
23.955 \\
\end{array}$} & \multirow{2}{*}{$\begin{array}{l}\text { \%RII } \\
91.790 \\
\end{array}$} & \multirow{2}{*}{$\begin{array}{c}\text { AI } \\
11.007\end{array}$} \\
\hline \multirow{6}{*}{ Invertebrates } & Ephemeroptera & & & & \\
\hline & Odonata & 0.412 & 0.028 & 0.706 & 0.031 \\
\hline & Decapoda & 0.046 & 0.001 & 1.988 & 0.106 \\
\hline & Orthoptera & 0.065 & 0.011 & 0 & 0 \\
\hline & Spirobolida & 0.058 & 0.007 & 0 & 0 \\
\hline & Hemiptera & 0.051 & 0.003 & 0 & 0 \\
\hline \multirow{4}{*}{ Fishes } & Cypriniformes & 0.388 & 0.181 & 0 & 0 \\
\hline & Perciformes & 0 & 0 & 0.567 & 0.087 \\
\hline & Characiformes & 0 & 0 & 0.350 & 0.037 \\
\hline & Fish remains & 3.372 & 1.427 & 0.298 & 0.025 \\
\hline Detritus & Detritus & 1.755 & 0.335 & 2.075 & 0.215 \\
\hline \multirow{3}{*}{ Plants } & Charales & 0.048 & 0.002 & 2.226 & 0.117 \\
\hline & Fabales & 0.060 & 0.008 & 0 & 0 \\
\hline & Total & 100 & & 100 & \\
\hline
\end{tabular}

Some studies on I. punctatus suggest that the spatial and temporal variability of its feeding is due to multiple factors, among which stand out: availability of resources, ontogeny, physicochemical quality of water (mainly temperature), seasonality and interspecific competition. The interaction of these factors results in the composition of the diet for a given period (Haubrock et al., 2018; Schmitt et al., 2018). Because of its broad food spectrum, which includes aquatic and terrestrial resources, the channel catfish has been cataloged historically as an omnivorous-opportunistic species; generally, this diet presents variations in relation to the seasonal availability of resources (Edds et al., 2002; Dagel et al., 2010; Cardoza et al., 2011; Braun \& Phelps, 2016).

Studies for the species in reservoirs in the semi-arid zone of northern Mexico have shown that the catfish is generalist and flexible in its diet throughout the year. (Cardoza et al., 2011). In the present study, this generalist behavior was consistent, because the food spectrum for the catfish in the Venustiano Carranza Dam consisted of 13 different taxonomic orders and the dominant items consumed show variability in relation to the seasons. Except for the order Ephemeroptera, all food items consumed annually were classified as accidental foods, since the individuals examined consumed significant amounts (high volume) of a specific food type in short periods of time (low frequency). However, certain preference for some types of food is reported for some reservoirs; for example, the preference for some species of forage fishes for the Lázaro Cárdenas Dam in Durango state, Mexico (Cardoza et al., 2011). It is worth highlighting the role of the order Ephemeroptera in feeding of the catfish for the period evaluated. Although it reached only the category as a secondary food for the winter season, the order Ephemeroptera occurred in three of 
four seasons and was the only food that was not classified as accidental in the total annual balance. The particular importance of this order and other groups of insects has also been reported for other catfish populations (Hill et al., 1995; Dagel et al., 2010; Hilling et al., 2016). Changes in catfish food preferences in relation to the seasons are also a reflection of their opportunistic and broad-spectrum eating habits (Braun \& Phelps, 2016). The present study confirms this, through the occurrence in specific seasons of some food types, such as the orders Ephemeroptera and Odonata, that use the aquatic environment as reproduction site. We also emphasize the importance of algae (Charales) and Detritus for catfish feeding in the dam throughout the year. Although both items are cataloged in the annual balance as accidental food, they practically occur in all four seasons of the year, which represents a frequent resource for the catfish population. In the case of algae, there are studies from reservoirs in North America that suggest that the consumption of algae as part of the catfish diet is very important. Far from being accidentally consumed by individuals, the algae become selected food of a spectrum available in the aquatic environment (Dagel et al., 2010; Cardoza et al., 2011). The highest consumption of food in weight and volume documented in this study for the winter season, compared to other periods of the year is probably a result of the preparation of energy of the organisms for the reproductive period, which takes place from February to August, depending on the conditions such as water temperature or habitat (Wellburn, 1988). However, it is necessary to continue with investigations that complement the explanations of seasonal variability of catfish feeding. On the other hand, for systems of fisheries in reservoirs in Mexico, there are general norms that regulate the exploitation of commercial species such as catfish, which includes minimum catch sizes, amount of daily catch per species, establishment of periods of no-fishing or "veda", among other general aspects (DOF, 2006). However, despite the fact that the channel catfish is one of the most important freshwater species for food and recreation through semi-intensive and extensive cultivation in reservoirs, for the majority of fisheries there are no comprehensive, management programs that ensure their viability and sustainability over time (Braun and Phelps, 2016; Lara-Rivera et al., 2015). Therefore, we consider it important for future planning and management to include the integral conservation of the reservoir system, specifically the conservation and restoration of riparian vegetation in the middle and upper part of the basin, avoiding ecosystem fragmentation (mainly by dams), maintaining, and recovering the original vegetation that surrounds the reservoir (Schnier et al., 2016). Some food types such as insects (Ephemeroptera and Odonata), algae (Charales) and Detritus are important components for catfish feeding and they need an acceptable biological integrity of the environment surrounds the reservoir to be available for fish populations. Numerous studies demonstrate the importance of the integrity of river and reservoir systems as a measure to favor the provision of food sources for channel catfish (Cardoza et al., 2011; Edds et al., 2002; Dagel et al., 2010; Braun and Phelps, 2016). 


\section{CONCLUSIONS}

Thirteen food items for annual catfish spectrum were determined. The most important food was the order Ephemeroptera, since it was the only one that reached the annual category as frequent food. We detected seasonal differences in feeding of the catfish. For spring and autumn all foods were categorized as accidental, while for the summer and winter the Detritus and the order Ephemeroptera were categorized as frequent and secondary, respectively. In the winter season, more food was consumed compared to the other seasons of the year. There was no difference in food intake between females and males. Further complementary studies on the evaluation of the diet of other commercial and non-commercial species and their interaction in terms of competition with the channel catfish, determination of variability in feeding based on the species ontogeny, determination of areas of importance within the reservoir (important nutrition zones), assessments of population ecology, among others, are recommended.

\section{REFERENCES}

Arce-H, M., Lundberg, J.G. \& O'Leary, A. (2017). Phylogeny of the North American catfish family Ictaluridae (Teleostei: Siluriformes) combining morphology, genes and fossils. Cladistics, 33, 406-428.

Behzadi, S., Kamrani, E., Kaymaram, F. \& Ranjbar, M.Sh. (2018). Trophic level, food preference and feeding ecology of Rachycentron canadum (Linnaeus, 1766), in Hormuzgan Province waters (northern Persian Gulf and Oman Sea). Iranian Journal of Fisheries Sciences, 17, 179-193

Beltrán-Álvarez, R., Sánchez-Palacios, J., Farías-Sánchez, A. \& Ramírez-Lozano, J.P. (2012). Aspectos reproductivos de la lobina negra (Micropterus salmoides) en la presa José López-Portillo, El Comedero, Sinaloa, México. Ciencia Pesquera, 65-75.

Braun, P.B. \& Phelps, Q.E. (2016). Channel Catfish Habitat Use and Diet in the Middle Mississippi River. The American Midland Naturalist, 175, 47-54.

Cardoza, G.F., Estrada, J.L., Alonzo, F., Mar, C.L. \& Gelwick, F. (2011). Espectro trófico del bagre Ictalurus punctatus (Siluriformes: Ictaluridae), en la presa Lázaro Cárdenas, Indé, Durango, México. Hidrobiológica, 21, 210-216.

Dagel, J., Wellner, M.R. \& Willis, D.W. (2010) Channel catfish diets include substantial vegetation in a Missouri River Reservoir. The Praire Naturalist, 42, 1-7.

Edds, D.R., Matthewrs, W.J. \& Gelwick, F.P. (2002). Resource use by large catfishes in a reservoir: Is there evidence for interactive segregation and innate differences? Journal of Fish Biology, 60, 739-750.

Espinosa-Pérez, H. (2014). Protocolo de muestreo de peces en aguas continentales para la aplicación de la Norma de Caudal Ecológico (NMX-AA-159-SCFI-2012). Programa Nacional de Reservas de Agua. Comisión Nacional del Agua, Fondo Mundial para la Naturaleza, México, 29 p.

Essner, R.L., Patel, R. \& Reilly, S.M. (2014). Ontogeny of Body Shape and Diet in Freshwater Drum (Aplodinotus grunniens). Transactions of the Illinois State Academy of Science, 107, 27-30.

Fisher, B., Naidoo, R., Guernier, J., Johnson, K., Mullins, D., Robinson, D. \& Allison, E.H. (2017). Integrating fisheries and agricultural programs for food security. Agriculture \& Food Security, 6, 1. Doi: https://doi.org/10.1186/s40066-016-0078-0

Gerringer, M.E., Popp, B.N., Linley, T.D., Jamieson, A.J. \& Drazen, J.C. (2017). Comparative feeding ecology of abyssal and hadal fishes through stomach content and amino acid isotope analysis. Deep-Sea Research I, 121, 110-120.

Jacquemin, S.J., Pyron, M., Allen, M. \& Etchison, L. (2014). Wabash River Freshwater Drum Aplodinotus grunniens Diet: Effects of Body Size, Sex, and River Gradient. Journal of Fish and Wildlife Management, 5, 133-140. 
Hammer, Ø., Harper, D.A.T. \& Ryan, P.D. (2001). PAST: Paleontological statistics software package for education and data analysis. Palaeontologia Electronica, 4, 1-9.

Haubrock, P.J., Balzani, P., Johovic, I., Inghilesi, A.F., Nocita, A. \& Tricarico, E. (2018). The diet of the alien channel catfish Ictalurus punctatus in the River Arno (Central Italy). Aquatic Invasions, 13, 575-585.

Hill, T.D., Duffy, W.G. \& Thompson, M.R. (1995). Food habits of channel catfish in Lake Oahe, South Dakota. Journal of Freshwater Ecology, 10, 319-323.

Hilling, C.D., Welsh, S.A. \& Smith, D.M. (2016). Age, Growth, and Fall Diet of Channel Catfish in Cheat Lake, West Virginia. Journal of Fish and Wildlife Management, 7, 304-314.

INEGI (Instituto Nacional de Estadística y Geografía). (2017). Conjunto Nacional de uso de suelo y vegetación: Escala 1:250 000 (vectorial). Serie VI. Instituto Nacional de Estadística y Geografía: México. Available online: http://www.conabio.gob.mx/ informacion/metadata/gis/usv250s6gw.xml?_httpcache=yes\&_xsl=/db/metadata/xsl/fgdc_html.xsl\&_indent=no (Accessed On 15 October 2018).

Lara-Rivera, A.L., Parra-Bracamonte, G.M., Sifuentes-Rincón, A.M., Gojón-Báez, H.H., Rodríguez-González, H. \& MontelongoAlfaro, I.O. (2015). El bagre de canal (Ictalurus punctatus Rafinesque, 1818): estado actual y problemática en México. Latin American Journal of Aquatic Research, 43, 424-434.

Lauzanne, L. (1975). Régime alimentaire d'Hidrocyon forskali (Pisces: Characidae) dans le lac Tchad et ses tributaries. Cahiers ORSTOM. Série Hidrologie, 9, 105-121.

Magnusson, W.E., Lima, A.P., Silva, Q.A. \& Araujo, M.C. (2003). Use of Geometric Forms to Estimate Volume of Invertebrates in Ecological Studies of Dietary Overlap. Copeia, 1, 13-19.

Mar, V., Hernández, R. \& Medina, M. (2014). Métodos clásicos para el análisis del contenido estomacal en peces. Biológicas, 16, 13-16.

Pinkas, L., Oliphant, M.S. \& Iverson, L.R. (1970). Food habits of albacore, bluefin tuna, and bonito in California waters. Fish Bulletin, 152, 1-105.

Raymundo-Huizar, A.R. \& Saucedo, M. (2008). Hábitos alimentarios del pez triglido Prionotus ruscarius (Gilbert \& Starks, 1904) durante 1996, en las costas de Jalisco y Colima, México. Revista de Biología Marina y Oceanografía, 43, 7-15.

Schmitt, J.D., Peoples, B.K., Castello, L. \& Orth, D.J. (2019). Feeding ecology of generalist consumers: a case study of invasive blue catfish Ictalurus furcatus in Chesapeake Bay, Virginia, USA. Environmental Biology of Fishes, 102, 443-465.

Schnier, S., Cai, X. \& Cao, Y. (2016). Importance of natural an anthropogenic environmental factors to fish communities of the Fox River in Illinois. Environmental Management, 57, 389-411.

Tyus, H. \& Nikirk, N. (1990). Abundance, growth and diet of channel catfish Ictalurus punctatus en the Green and Yampa Rivers, Colorado and Utah. The Southwestern Naturalist, 35, 188-198.

Valdez-Zenil, J., Rodiles-Hernández, R., González-Acosta, A.F., Barba-Macías, E. \& Mendoza-Carranza, M. (2015). Abundancia relativa, estructura de tallas y relación longitud-peso de la mojarra mexicana Eugerres mexicanus. Ecosistemas y Recursos Agropecuarios, 2, 349-356.

Wellburn, T. (1988). Channel catfish - Life History and Biology. Southern Regional Aquaculture Center, n. 180.

Zar, J.H. 1999. Bioestatistical analysis. $3^{\text {rd }}$ ed.; Prentice Hall: New Jersey, USA. 988 p. 